\title{
An Update on Ethanol Production and Utilization in Thailand
}

\author{
Cary Bloyd
}

October 2009

\section{Pacific Northwest}

NATIONAL LABORATORY 


\title{
DISCLAIMER
}

This report was prepared as an account of work sponsored by an agency of the United States Government. Neither the United States Government nor any agency thereof, nor Battelle Memorial Institute, nor any of their employees, makes any warranty, express or implied, or assumes any legal liability or responsibility for the accuracy, completeness, or usefulness of any information, apparatus, product, or process diselosed, or represents that its use would not infringe privately owned rights. Reference herein to any specific commercial product, process, or service by trade name, trademark, manufacturer, or otherwise does not necessarily constitute or imply its endorsement, recommendation, or favoring by the United States Government or any agency thereof, or Battelle Memorial Institute. The views and opinions of authors expressed herein do not necessarily state or reflect those of the United States Government or any agency thereof.

\author{
PACIFIC NORTHWEST NATIONAL LABORATORY \\ operated by \\ BATTELLE \\ for the \\ UNITED STATES DEPARTMENT OF ENERGY \\ under Contract DE-AC05-76RL01830 \\ Printed in the United States of America
Available to DOE and DOE contractors from the
Office of Scientific and Technical Information,
P.O. Box 62, Oak Ridge, TN 37831-0062;
ph: (865) 576-8401
fax: (865) 576-5728
email: reports@adonis.osti.gov

\footnotetext{
Available to the public from the National Technical Information Service,

U.S. Department of Commerce, 5285 Port Royal Rd., Springfield, VA 22161

ph: (800) 553-6847

fax: (703) 605-6900

email: orders@ntis.fedworld.gov

online ordering: http://www.ntis.gov/ordering.htm
}

This document was printed on recycled paper.

$(9 / 2003)$ 


\section{An Update on Ethanol Production and Utilization in Thailand}

CN Bloyd

October 2009

Prepared for the U.S. Department of Energy under Contract DE-AC05-76RL01830

Pacific Northwest National Laboratory

Richland, Washington 99352 


\section{An Update on Ethanol Production and Utilization in Thailand}

Thailand has continued to promote domestic biofuel utilization. Production and consumption of biofuel in Thailand have continued to increase at a fast rate due to aggressive policies of the Thai government in reducing foreign oil import and increasing domestic renewable energy utilization.

This paper focuses on ethanol production and consumption, and the use of gasohol in Thailand. The paper is an update on the previous paper-Biofuel Infrastructure Development and Utilization in Thailand-in August 2008.

\section{Ethanol Production}

As of June 2009, there are a total of fifteen commercial ethanol plants, with total installed capacity of 2.275 million liters per day (see Table 1 ). This is 0.7 million liters per day more than last reported in August 2008 as four more ethanol plants started their operation in 2009. Eight additional ethanol plants (mainly using cassava as a feedstock) are being constructed with an additional capacity of 3.42 million liters per day (see Table 2). As of April 2009, 47 more ethanol plants received construction permits with total production capacity of 12.295 million liters per day.

Table 1: Existing Ethanol Plants in Thailand (June 2009)

\begin{tabular}{|c|c|c|c|c|}
\hline Company & $\begin{array}{c}\text { Installed } \\
\text { Capacity } \\
\text { (L/day) }\end{array}$ & Feedstock & Province & $\begin{array}{c}\text { Commencing } \\
\text { Date }\end{array}$ \\
\hline $\begin{array}{l}\text { 1. Pornwilai International } \\
\text { Group }\end{array}$ & 25,000 & Molasses & Ayuddhaya & Oct 03 \\
\hline 2. Thai Alcohol & 200,000 & Molasses & Nakhon-Pathom & Aug 04 \\
\hline 3. Thai Agro Energy & 150,000 & Molasses & Suphanburi & Jan 05 \\
\hline 4. Thai Nguan Ethanol & 130,000 & Cassava & Khon Khan & Aug 05 \\
\hline 5. Khon Khan Alcohol & 150,000 & $\begin{array}{l}\text { Sugarcane } \\
\text { /Molasses }\end{array}$ & Khon Khan & Jan 06 \\
\hline 6. PetroGreen & 200,000 & $\begin{array}{l}\text { Sugarcane } \\
\text { /Molasses }\end{array}$ & Chaiyaphoom & Dec 06 \\
\hline 7. Thai Sugar Ethanol & 100,000 & $\begin{array}{l}\text { Sugarcane } \\
\text { /Molasses }\end{array}$ & Kanchanaburi & Apr 07 \\
\hline 8. KI Ethanol & 100,000 & $\begin{array}{l}\text { Sugarcane } \\
\text { /Molasses }\end{array}$ & $\begin{array}{l}\text { Nakhon } \\
\text { Ratchasima }\end{array}$ & Jun 07 \\
\hline 9. PetroGreen & 200,000 & $\begin{array}{l}\text { Sugarcane } \\
\text { /Molasses }\end{array}$ & Kalaseen & Jan 08 \\
\hline 10. Ekarat Pattana ${ }^{1 /}$ & 200,000 & Molasses & Nakhonsawan & Mar 08 \\
\hline 11. Thai Rung Ruang Energy & 120,000 & $\begin{array}{l}\text { Sugarcane } \\
\text { /Molasses }\end{array}$ & Saraburi & Mar 08 \\
\hline 12. Ratchaburi Ethanol & 150,000 & $\begin{array}{l}\text { Cassava/ } \\
\text { Molasses }\end{array}$ & Ratchaburi & Jan 09 \\
\hline 13. ES Power & 150,000 & $\begin{array}{l}\text { Molasses/ } \\
\text { Cassava }\end{array}$ & Sakaew & Jan 09 \\
\hline
\end{tabular}


PNNL-19060

\begin{tabular}{|l|r|l|l|l|}
\hline \multicolumn{1}{|c|}{ Company } & $\begin{array}{c}\text { Installed } \\
\text { Capacity } \\
\text { (L/day) }\end{array}$ & Feedstock & Province & $\begin{array}{c}\text { Commencing } \\
\text { Date }\end{array}$ \\
\hline 14. Maesawd Clean Energy & 200,000 & Sugarcane & Tak & May 09 \\
\hline 15. SupThip & 200,000 & Cassava & Lopburi & May 09 \\
\hline Total & $\mathbf{2 , 2 7 5 , 0 0 0}$ & & & \\
\hline
\end{tabular}

Note: ${ }^{1 /}$ Production for exporting, $95 \%$ purity

Source: www.dede.go.th/dede/fileadmin/upload/pictures_eng/pdffile/Existing_Ethanol_Plant.xls

Table 2: Ethanol Plants under Construction

\begin{tabular}{|l|r|l|l|l|}
\hline \multicolumn{1}{|c|}{ Company } & $\begin{array}{c}\text { Installed } \\
\text { Capacity } \\
\text { L/day }\end{array}$ & Feedstock & \multicolumn{1}{|c|}{ Province } & \multicolumn{1}{|c|}{$\begin{array}{c}\text { Expected } \\
\text { Operation }\end{array}$} \\
\hline 1. TaiPing Ethanol & 150,000 & Cassava & Sakaew & Jul 09 \\
\hline $\begin{array}{l}\text { 2. PSC Starch } \\
\text { Production }\end{array}$ & 150,000 & Cassava & Chonburi & Oct 09 \\
\hline 3. PTK Ethanol-Phase 1 & 340,000 & Cassava & Nakhonratchasima & Jan-Mar 10 \\
\hline \multicolumn{1}{|c|}{ PTK Ethanol-Phase 2 } & 680,000 & Cassava & Nakhonratchasima & Jun-July 10 \\
\hline $\begin{array}{l}\text { 4. PetroGreen } \\
\text { (Suphanburi) }\end{array}$ & 200,000 & Molasses & Suphanburi & Dec 09 \\
\hline $\begin{array}{l}\text { 5. Impressed } \\
\text { Technology }\end{array}$ & 200,000 & Cassava & ChaChoengSao & May 10 \\
\hline 6. Boon Anak & $1,050,000$ & Cassava & Nakhonratchasima & N/A \\
\hline 7. Sima Inter Products & 150,000 & Cassava & Chasengsao & N/A \\
\hline 8. Double A Ethanol & 500,000 & Cassava & Pracheenburi & Mar 10 \\
\hline Total & $\mathbf{3 , 4 2 0 , 0 0 0}$ & & & \\
\hline
\end{tabular}

Source: www.dede.go.th/dede/fileadmin/upload/pictures_eng/pdffile/Existing_Ethanol_Plant.xls

The actual production of ethanol (January 2009) is at 1.33 million liters per day-an increase of 51\% over the average production of 0.88 million liter per day in 2008 (see Table 3). The Energy Ministry has targeted the use of ethanol at 9 million liters per day in 2023.

Table 3: Ethanol Production in 2006-2009

\begin{tabular}{|l|c|c|}
\hline & Million Liter & Million Liter/Day \\
\hline 2006 & 135.35 & 0.37 \\
\hline 2007 & 191.75 & 0.53 \\
\hline 2008 & 322.19 & 0.88 \\
\hline January 2009 & 41.30 & 1.33 \\
\hline
\end{tabular}

Source: DEDE

\section{Ethanol Pricing ${ }^{1}$}

Ethanol in Thailand is priced by referring to the ethanol FOB price at the Brazilian Commodity Exchange San Paolo in Brazil. This price is then adjusted by adding on freight, insurance, loss, and other costs (e.g., survey/shipping/testing). Freight composes of a

${ }^{1}$ www.dede.go.th/dede/fileadmin/upload/pictures_eng/pdffile/ethanol_pricing_formulation.doc 
domestic freight in transporting ethanol in Brazil from Sao Paulo to Santos, and international freight in transporting ethanol from Brazil to Thailand. An insurance cost is calculated as $0.0134 \%$ of CFR value. Loss is estimated at $0.20 \%$ of CIF value, and survey/shipping/testing cost is estimated at a fixed rate of $0.008 \mathrm{baht} / \mathrm{liter}$.

\section{Ethanol Consumption}

The current blends of ethanol with gasoline in the Thai market are E10 (10\% ethanol with 90\% gasoline) in Octane 91 and Octane 95, E20 (20\% ethanol with 80\% of gasoline) in Octane 95, and E85 in Octane 95 (85\% of ethanol with 15\% of gasoline). Sales of gasohol in Thailand have been increasing continually since the start in 2004 (see Table 4). The most recent available data of gasohol sales in Thailand was for the month of January 2009 at 390.01 million liter or 12.581 million liter per day (as compared to the sales of gasohol in January 2008 at 220.84 million liters or 7.124 million liter per day).

Table 4: Gasohol Sales in Thailand (including E10 Octane 91, E10 Octane 95, E20, and E85)

\begin{tabular}{|l|c|c|c|}
\hline & Million Liter & Million Liter/Day & $\begin{array}{c}\text { \% Change of Sales } \\
\text { Per Day }\end{array}$ \\
\hline 2004 & 59.50 & 0.16 & $(1081 \%)$ \\
\hline 2005 & 690.23 & 1.89 & $(85.2 \%)$ \\
\hline 2006 & $1,279.30$ & 3.50 & $(38.0 \%)$ \\
\hline 2007 & $1,762.76$ & 4.83 & $(90.9 \%)$ \\
\hline 2008 & $3,391.73$ & 9.221 & $(36.4 \%)$ \\
\hline January 2009 & 390.01 & 12.581 & \\
\hline
\end{tabular}

Source: Department of Alternative Energy Development and Efficiency

Production and sales of E10 increased drastically in 2008 as compared to 2007. The production of E20 began in 2007, and of E85 in 2008 (see Table 5).

Table 5: Production and Sales of Gasohol in 2007 and 2008

\begin{tabular}{|l|c|c|c|c|}
\hline & \multicolumn{2}{|c}{ Production } & \multicolumn{2}{c|}{ Unit: Million Liters } \\
\cline { 2 - 5 } & $\mathbf{2 0 0 7}$ & $\mathbf{2 0 0 8}$ & $\mathbf{2 0 0 7}$ & $\mathbf{2 0 0 8}$ \\
\hline E10-Octane 91 & 248.160 & 928.730 & 244.256 & 923.501 \\
\hline E10-Octane 95 & $1,516.133$ & $2,435.466$ & $1,518.507$ & $2,439.182$ \\
\hline E20 & 0.047 & 29.395 & & 29.028 \\
\hline E85 & & 0.037 & & 0.021 \\
\hline & $1,764.34$ & $3,393.628$ & $1,762.763$ & $3,391.732$ \\
\hline
\end{tabular}

Source: www.doeb.go.th/information/info_conclude51.htm

The largest distributor of gasohol in Thailand is the PTT Public Company (PTT). The other major distributors include Bangchak Petroleum Public Company (Bangchak), Shell Thailand, Esso, and Chevron Thailand. Presently, PTT and Bangchak are the only two distributors of E20 and E85. The shares of gasohol sales by distributors in 2008 are shown in Table 6. 
PNNL-19060

Table 6: Shares of Gasohol Sales in Thailand by Distributor in 2008

\begin{tabular}{|l|l|l|l|l|}
\hline & \multicolumn{5}{c|}{ U10-Octane 91 } & E10-Octane 95 & E20 & E85 \\
\hline PTT & $360.272(39.0 \%)$ & 729.553 & 17.931 & 0.017 \\
& & $(29.9 \%)$ & $(61.8 \%)$ & $(81.0 \%)$ \\
\hline Bangchack & 30.821 & 233.270 & 11.097 & 0.004 \\
& $(3.3 \%)$ & $(9.6 \%)$ & $(38.2 \%)$ & $(19.0 \%)$ \\
\hline Shell & 85.191 & 445.640 & & \\
& $(9.2 \%)$ & $(18.3 \%)$ & & \\
\hline Esso & 50.320 & 371.978 & & \\
& $(5.4 \%)$ & $(15.3 \%)$ & & \\
\hline Chevron & 8.521 & 291.527 & & \\
& $(0.9 \%)$ & $(12 \%)$ & & \\
\hline Others & 388.376 & 367.214 & & $\mathbf{0 . 0 2 1}$ \\
& $(42.1 \%)$ & $(15.1 \%)$ & & \\
\hline Total Sales & $\mathbf{9 2 3 . 5 0 1}$ & $\mathbf{2 , 4 3 9 . 1 8 2}$ & $\mathbf{2 9 . 0 2 8}$ & \\
\hline
\end{tabular}

Source: www.doeb.go.th/information/stat/stat_gasohol.xls

As of August 2009, there are total of 6,981 petro stations across the country selling gasohol. Majority of them is selling E10 Octane 95. Since E20 and E85 were introduced to the market in 2008, the petro stations offering these products are still limited and are mainly located in the Bangkok Metropolitan Area (see Table 7). However, both PTT and Bangchak have plans to open more petro stations for E20 and E85 all over the country to meet future growing demand.

Table 7: Numbers of petro stations selling gasohol (August 2009)

\begin{tabular}{|l|c|c|c|c|}
\hline & E10 Octane 91 & E10 Octane 95 & E20 & E85 \\
\hline PTT & 801 & 1,133 & 117 & 3 \\
\hline Bangchak & 804 & 720 & 117 & 1 \\
\hline Shell & 375 & 584 & & \\
\hline Esso & 336 & 550 & & \\
\hline Chevron & 191 & 418 & & \\
\hline Petronas & 76 & 116 & & \\
\hline $\begin{array}{l}\text { Siam- } \\
\text { Sahaborikan }\end{array}$ & & 143 & & \\
\hline Others & 98 & 398 & & \\
\hline Total & $\mathbf{2 , 6 8 1}$ & $\mathbf{4 , 0 6 2}$ & $\mathbf{2 3 4}$ & $\mathbf{4}$ \\
\hline
\end{tabular}

Source: www.doeb.go.th/information/stat/stat_gasohol.xls

Prices per liter of E10, E20 and E85 are shown in Table 8. These were prices of gasohol from PTT petro stations in the Bangkok Metropolitan Areas. The price of E20 is 2 baht per liter less than that of E10 Octane 95 (the same octane as E20) and 6 baht per liter less than that of gasoline octane 95-due to the government's policy and subsidies. ${ }^{2}$

${ }^{2}$ In October 2009, \$1=33.385 baht 
PNNL-19060

Table 8: Prices of Gasohol in the Bangkok Metropolitan Areas (on October 17, 2009) Unit: Baht/Liter

\begin{tabular}{|l|c|}
\hline Gasohol 91 (E10 Octane 91) & 29.74 \\
\hline Gasohol 95 (E10 Octane 95) & 30.24 \\
\hline E20 Plus (E20) & 28.24 \\
\hline E85 Plus (E85) & 18.72 \\
\hline PTT ALPHA-X95 (Gasoline Octane 95) & 34.24 \\
\hline
\end{tabular}

Source: www.pttplc.com/th/nc_oi.aspx

\section{Update on E10}

E10 was the first ethanol product to be used in the Thai market. It is sold as Gasohol 95 and Gasohol 91 (which is $10 \%$ of gasoline octane 95 or of gasoline octane 91 blended with $10 \%$ ethanol). About 80\% of E10 production and consumption are Gasohol 95. The sales of Gasohol 91 increase from 244.256 million liters in 2007 to 923.501 million liters in 2008; and those of Gasohol 95 increased from 1,518.5 million liter in 2007 to 2,439.18 million liter in 2008. As of August 2009, total of 6,743 petro stations all over the country are selling E10. To build the public's confidence in using E10 in their cars, the government provides a list of car models manufactured in various years that can be fueled safely by E10. In general, cars with fuel injection systems that were manufactured from 1995 and onwards are safely fueled by E10.

\section{Update on E20}

E20 was introduced to the Thai market for the first time on January 1, 2008. PTT was the first company selling E20 and used the commercial name of "PTT E20 Plus". Later on Bangchak entered the E20 market and was the second producer and distributor of E20 in Thailand.

A total of 29.028 million liters of E20 were consumed in 2008. Of the total, 61.8\% or 17.931 million liters was the PTT E20 Plus by PTT. It was reported that in 2009 PTT's sales of E20 is about 2.7 million liters per month, which almost doubles from 1.494 million liter per month in $2008 .^{4}$

E20 is recommended to be utilized on specific car models as suggested by the original equipment manufacturer (OEM). At present, six automobile companies are selling E20 capable cars. Those include:

- Ford-Focus and Escape 3000 CC

- Honda-Accord, CR-V, Civic and City

- Mazda-Mazda 3

- Nissan-Tida and Teana

- Mitsubishi-Space Wagon and Lancer

- Toyota-Corolla, Vios, Yaris, Altis, and Camry

${ }^{3}$ www.dede.go.th/dede/index.php?id=118

${ }^{4}$ Bangkok Post, July 27, 2009, “Gasohol Losses May Curb E20 Sales; Ethanol Prices Reflect Sugar Spike” by Yuthana Praiwan; see www.istockanalyst.com/article/viewiStockNews/articleid/3374300 
Ford Focus and Ford Escape 3000 CC have been available in the Thai market since 2005, while the other models have been sold since 2008. The government has provided a guideline that cars manufactured for E20 can also be fueled by gasoline octane 95 and E10 octane 95. About 60,000 of E20 capable cars were sold in Thailand in 2008. The Thailand Automobile Institute forecasts that there will be 610,000 E20 compatible vehicles on the street in 2011.

At present there are 234 petro stations selling E20 across the country—of which half are owned by PTT and the other half are owned by Bangchak.

The Thai government is implementing various policies to support E20 as well as E20 capable cars. As an incentive for people to use more E20, the retail price of E20 is set to be 2.0 baht per liter lower than the retail price of E10 Octane 95 (Gasohol 95) and 6 baht per liter lower than that of gasoline 95. For example, the retail price of E20 on October 20, 2009 was 28.24 baht per liter, and those of Gasohol 95 and gasoline 95 on the same day were 30.24 baht and of 34.24 baht per liter, respectively.

In addition, the Ministry of Finance has issued a notification effective from January 1, 2008 to reduce excise tax for cars capable of utilizing E20 as follows:

- Cars with cylinder capacity less than 2,000 cc and engine power not over $220 \mathrm{HP}$, an excise tax rate was reduced from $30 \%$ to $25 \%$.

- Cars with cylinder capacity between 2,000 cc to 2,500 cc and engine power not over $220 \mathrm{HP}$, an excise tax rate was reduced from 35\% to $30 \%$.

- Cars with cylinder capacity over 2,500 cc but less than 3,000 cc and engine power not over $220 \mathrm{HP}$, an excise tax rate was reduced from $40 \%$ to 35\%.

- Cars with cylinder capacity over 3,000 cc or engine power over $220 \mathrm{HP}$, an excise tax rate was fixed at the same previous rate of $50 \%$.

Cars that are eligible for these new excise tax rates must meet all the following requirements:

- Cars must be designed to be fueled by gasoline with a minimal $20 \%$ blended with ethanol, and must be manufactured by the original car company.

- Cars must be guaranteed by their manufacturer for its capability to be fueled by gasoline with a minimal $20 \%$ blended with ethanol.

- Cars must be certified by the Thailand Industrial Standard Institute (TISI)'s Pollution Standard Accreditation for emission rates lower than TIS 2160-2546. ${ }^{5}$

These reduced excise tax rates make prices of E20 fueled cars about 50,000 to 100,000 baht lower than if the old excise tax rates were employed.

${ }^{5}$ TIS 2160-2546 is the latest pollution standard adopted in Thailand for passenger cars run by gasoline. It has been effective since January 10, 2005. This standard is based on DRT 1999/102/EC(A) EURO3, and the emissions are measured immediately after starting the engine. The standards are separated between cars with not more than 6 seats and more than 6 seats. For not more than 6-seat-passenger cars, the pollution standards are $\mathrm{CO}<2.30 \mathrm{~g} / \mathrm{km}, \mathrm{HC}<0.20 \mathrm{~g} / \mathrm{km}$, and NOx $<0.15 \mathrm{~g} / \mathrm{km}$. For more than 6-seat-passenger cars, the pollution standards are CO between 2.30-5.22 g/km, HC between 0.20-0.29 g/km, and NOx between 0.15-0.21 g/km. See www.pcd.go.th/info_serv/reg_std_airsnd02.html 


\section{Update on E85}

Thailand introduced E85 (a blend of 85\% ethanol with 15\% gasoline) for flexible fuel vehicles (FFV) during the third Quarter of 2008, three years ahead of its earlier plan. PTT was the first distributor of E85 at its station at the MahaNakorn Expressway resting area. As of August 2009, there are a total of 4 petro stations selling E85 — of which three are owned by PTT and one by Bangchak. PTT has plans to open more E85 stations so that there will be 15 stations by the end of $2009 .^{6}$

In November 2008, Mr. Paul Stokes, the Executive President of the Volvo (Thailand) car company, and his staff visited the Energy Ministry to confirm their adoption of the Thai government's E85 promotion policy. The first FFV manufactured in Thailand-the Volvo S80 - was introduced in November 2008. At present, two FFV models are being manufactured in Thailand-Volvo S80 and Volvo C30.

A total of 0.021 million liters of E85 were sold in 2008 - of which $81 \%$ or 0.017 million liters was from PTT, and the rest was from Bangchak. It was reported that in 2009 PTT's sales of E85 are about 8,000 liters per month. ${ }^{7}$

In January 2009, in support of the Thai government's E85 promotion policy, two local companies-Mitrapol Group and PetroGreen-imported fifty E85 FFVs to Thailand for their companies' transportation. This was to show to the public that the commercial use of gasohol E85 in Thailand is more concrete.

Several measures are in place to promote the use of E85 in the country. Those include:

- Importation of 2000 FFVs for commercial fleet test uses,

- Plans to open 30-50 petro stations for E85 sales to support the new FFV fleet,

- Reduction of an import duty from $80 \%$ to $60 \%$ for the imported 2000 FFVs,

- Reduction of an excise tax for FFVs (both imported and manufactured domestically) to $3 \%^{8}$

- Approval of 357 million bath from the Oil Fund to compensate the difference of excise tax for the FFVs (effective in June 6, 2009),

- Defining the E85 fuel specification standard,

- Restructuring of oil pricing to make retail price of E85 lower than of gasohol 95 (E10)

- Establishing guidance to support E85 production in order to provide more supply to meet future demand, and to increase its production efficiency in the long run.

If the goal is reached, the use of E85 will save the country 447,377 million bath from oil imports in the next 10 years, and will help reduce pollution of 27.8 million ton per year, in addition to supporting the agricultural sector and increasing income for farmers.

${ }^{6}$ www.energy.go.th/moen/NewsDetail.aspx?id=265

7 Bangkok Post, July 27, 2009, “Gasohol Losses May Curb E20 Sales; Ethanol Prices Reflect Sugar Spike” by Yuthana Praiwan; see www.istockanalyst.com/article/viewiStockNews/articleid/3374300

8 The imported FFVs eligible for the reduced excise tax must have cylinder capacity between 2,000 cc to 2,500 cc, be imported by December 2009, and be for sales in the country. Only 2000 FFVs are allowed to receive this special privilege. 


\section{Conclusion}

The Thai government has established a clear policy to promote the use of alternative energy for sustainable development as determined in the Fifteen-Year Alternative Energy Development Plan of 2008-2023. The Thai Energy Ministry has placed alternative energy promotion policies, especially increasing ethanol use, at the front of the national agenda. A roadmap was developed to promote raw material/feedstock for ethanol production, to increase production efficiency of ethanol feedstocks and to increase planting areas for ethanol feedstocks. The government has monitored ethanol prices and gasohol to ensure competitiveness with gasoline. Ethanol production and gasohol consumption in Thailand has continued to increase in 2008 and 2009. In addition to E10, in 2008 E20 and E85 were introduced to the market. Various policies are being implemented to promote the use of E20 and E85 including a pricing policy to make gasohol cheaper than regular gasoline, and lowering taxes for E20 fueled cars and FFVs. In July 2009 ethanol prices have risen to 25 baht per liter from 20 bath per liter in June 2009 and 18 baht per liter in January 2009 in line with the costs of molasses because of a global sugar supply shortage. However, the Energy Minister confirmed strongly that the government will continue to support alternative fuels even though prices of alternative fuels at present are not competitive with those of mainstream fuels. The government will continue with subsidies, tax measures and Oil Fund levies to help make gasohol and other alternative fuels competitive in Thailand. 